\title{
Identification and functional characterization of the nascent RNA contacting residues of the hepatitis $C$ virus RNA-dependent RNA polymerase
}

\author{
ROBERT VAUGHAN, ${ }^{1}$ BAOCHANG FAN, ${ }^{1}$ JIN-SAM YOU, ${ }^{2}$ and C. CHENG KAO ${ }^{1,3}$ \\ ${ }^{1}$ The Biochemistry Interdisciplinary Program, Indiana University, Bloomington, Indiana 47405, USA \\ ${ }^{2}$ Indiana University School of Medicine, IUPUI, Indianapolis, Indiana 46202, USA
}

\begin{abstract}
Understanding how the hepatitis C virus (HCV) RNA-dependent RNA polymerase (RdRp) interacts with nascent RNA would provide valuable insight into the virus's mechanism for RNA synthesis. Using a peptide mass fingerprinting method and affinity capture of peptides reversibly cross-linked to an alkyn-labeled nascent RNA, we identified a region below the $\Delta 1$ loop in the fingers domain of the HCV RdRp that contacts the nascent RNA. A modification protection assay was used to confirm the assignment. Several mutations within the putative nascent RNA binding region were generated and analyzed for RNA synthesis in vitro and in the HCV subgenomic replicon. All mutations tested within this region showed a decrease in primer-dependent RNA synthesis and decreased stabilization of the ternary complex. The results from this study advance our understanding of the structure and function of the HCV RdRp and the requirements for HCV RNA synthesis. In addition, a model of nascent RNA interaction is compared with results from structural studies.
\end{abstract}

Keywords: hepatitis C virus; positive-strand RNA virus; NS5B RNA-dependent RNA polymerase; nascent RNA channel; RNA binding

\section{INTRODUCTION}

The causative agent of hepatitis $\mathrm{C}$, the hepatitis $\mathrm{C}$ virus (HCV), has become a well-studied system for viral RNA replication. HCV is a single-stranded RNA (ssRNA) virus in the Flaviviridae family. The key enzyme for HCV RNA replication and transcription is NS5B, the RNA-dependent RNA polymerase (RdRp). Studies of the HCV RdRp have provided useful information about interactions with inhibitors and insights to the requirements for viral RNAdependent RNA synthesis (Chinnaswamy et al. 2010a).

All polymerases can be described using the analogy of a right hand, with the fingers, thumb, and palm subdomains (Joyce and Steitz 1995). The fingers and thumb subdomains guide the template RNA, while the active-site motif resides in the palm (Ranjith-Kumar and Kao 2006). In vitro, the recombinant HCV RdRp is capable of initiating RNA synthesis de novo from purine nucleotides, which is the likely mechanism of RNA synthesis during infection (Ferrari et al.

\footnotetext{
${ }^{3}$ Corresponding author

E-mail ckao@indiana.edu

Article published online ahead of print. Article and publication date are at http://www.rnajournal.org/cgi/doi/10.1261/rna.031914.111.
}

1999; Bressanelli et al. 2002). GTP is the preferred initiation nucleotide in vitro and has recently been shown to stimulate the transition from initiation to elongation in trans (Harrus et al. 2010). Binding to the initiation nucleotide occurs through a region called the primer grip that lies adjacent to the divalent metal binding motif in the catalytic pocket of the HCV RdRp (Bressanelli et al. 2002; O'Farrell et al. 2003).

How the viral RdRp structure affects function has been the subject of considerable analysis (Appel et al. 2006; Powdrill et al. 2010; Rigat et al. 2010). The template channel has been characterized using proteomic approaches and mutational analysis (Kim et al. 2005; Deval et al. 2007). A complex of NS5B crystallized with a short RNA also provided valuable information on the interaction between the $5^{\prime}$ end of the single-stranded RNA template and the template channel (O'Farrell et al. 2003). A crystal structure of the HCV polymerase in a partially open form has also been determined (Biswal et al. 2005). It suggests that an extensive conformational change must occur for the HCV RdRp to accommodate the partial duplex formed between the template and nascent RNA (O'Farrell et al. 2003; Dutartre et al. 2005; Chinnaswamy et al. 2008). Single-molecule reconstructions of the monomeric form of the HCV RdRp 
as well as analysis of crystal structures of the HCV RdRp in complex with non-nucleoside inhibitors are consistent with large conformational changes being important for activities of the HCV RdRp (Chinnaswamy et al. 2010b; Caillet-Saguy et al. 2011). A key element involved in the conformational change is named the $\Delta 1$ loop, which extends from the fingers to contact the thumb subdomain largely through hydrophobic interactions (Chinnaswamy et al. 2008). Mutations or inhibitors that affect the $\Delta 1$ loop-thumb interaction reduced de novo-initiated RNA synthesis and were detrimental for HCV subgenomic replicon replication (Tomei et al. 2003; Chinnaswamy et al. 2010a).

An important feature of RNA synthesis by the HCV RdRp that has not been determined experimentally is the location where the nascent RNA emerges from the ternary complex. This project seeks to map the nascent RNA channel and characterize how the channel affects RNA-dependent RNA synthesis.

\section{RESULTS}

\section{Identification of the nascent RNA channel of NS5B using mass spectrometry}

The goals of this study are to identify the nascent RNA exit site in the HCV RdRp and to examine its role in RNAdependent RNA synthesis. This study used the NS5B from the $1 \mathrm{~b}$ Con 1 strain that was expressed without the C-terminal membrane-anchoring residues. The resulting protein is named $1 \mathrm{~b} \Delta 21$. Previously, a reversible cross-linking-peptide fingerprinting method (RCAP) was used to map the regions of the polymerase that contact RNA (Kim et al. 2005). A technical challenge in the identification of the nascent RNA exit channel was the specific capture of the nascent RNA in the presence of molar excess of the template RNA. Therefore, we modified the RCAP assay (Fig. 1A) to include an alkynmodified 5-nt primer (5P) that can be extended in the nascent RNA channel to enable its specific capture using the highly efficient click chemistry (Speers and Cravatt 2004). Viral RdRps have been shown to use a 5-nt primer in place of GTP for de novo-initiated RNA synthesis (Ranjith-Kumar et al. 2002a). The template for the RNA synthesis reaction was a 12 -nt RNA (12T) that has $5 \mathrm{nt}$ at its $3^{\prime}$ terminus that can anneal with $5 \mathrm{P}$ as well as allow stepwise extension from $5 \mathrm{P}$ by the addition of specific NTP(s) (Fig. 1B).

To ensure that the HCV RdRp can perform stepwise synthesis with the 5P/12T RNA complex, one or more NTPs were added to the reactions, and the lengths of the products were monitored (Fig. 1C). The presence of only ATP resulted in no obvious product synthesis, due to the need to incorporate two uridylates after 5P. Similar results were observed in reactions with only CTP. In the presence of radiolabeled UTP, products extended from 5P of 6-9 nt were observed. While only the 6-nt to 7-nt products are expected based on the template sequence, the HCV RdRp has been reported to add nontemplated nucleotides to the $3^{\prime}$ terminus of the nascent RNA (Ranjith-Kumar et al. 2001). Interestingly, in the presence of both UTP and ATP, the majority of the products were of 10 and $11 \mathrm{nt}$. In the presence of the 5P primer, UTP, ATP, and CTP, the products were further extended to be of 11 and $12 \mathrm{nt}$ (Fig. 1C). The 12 -nt product represents a complete template-dependent RNA synthesis, while the 11-nt product terminated prematurely. RdRps have been documented to terminate prematurely if the template contains adenylates and uridylates at positions -2 to -4 from the $5^{\prime}$ terminus (Kim et al. 2000; Tayon et al. 2001). Synthesis of all of the products required the 5P/primer (Fig. 1C). These results have been independently confirmed in more than five independent experiments that manipulated the various NTP concentrations. While the pausing of the $1 \mathrm{~b} \mathrm{RdRp}$ elongation products was imprecise, these results demonstrate that intermediates in RNA synthesis could be produced in the absence of one or more of the NTPs.

The conditions used to form the ternary complex in an NTP-dependent manner were used for the RCAP assay. Reactions performed with $1 \mathrm{~b} \Delta 21$ incubated with only $5 \mathrm{P}$ or with the $5 \mathrm{P} / 12 \mathrm{~T}$ complex but no NTPs, were processed in parallel to serve as controls for the identification of regions of the $1 \mathrm{~b} \Delta 21$ that can contact RNA (but not specifically 
contact the nascent RNA exit site). Several peptides associated with $5 \mathrm{P}$ or $5 \mathrm{P} / 12 \mathrm{~T}$ were identified (Fig. $2 \mathrm{~A}$ ). Upon the addition of UTP, two peptides in addition to those identified with $5 \mathrm{P}$ or $5 \mathrm{P} / 12 \mathrm{~T}$ were reproducibly observed. The first contained residues 49-56 that mapped to the base of the $\Delta 1$ loop, while the second mapped to residues 511517 (Fig. 2A,B). When both UTP and ATP were present in the reaction, peptide consisting of residues 66-72 was observed. Since this peptide was located next to amino acids 49-56 in the NS5B structure (Fig. 2B), we hypothesize that residues 49-72 contact the nascent RNA.

When viewed from the front face of the RdRp, residues 49-72 are located on the right side of the central cavity of the HCV RdRp, while the primer grip is located to the left side of the cavity (Fig. 2B). This result suggests that the nascent RNA needs to turn from the left side of the polymerase to the right in its path out of the central cavity. To confirm that the region encompassed by peptide $49-72$ does contact the nascent RNA using an independent method, we incorporated aminoallyl-UTP in place of UTP in the RNA synthesis reaction that will add a free amine for cross-linking. Aminoallyl-uridylate can be used by the HCV RdRp in the RNA synthesis assay (Supplemental Fig. 1). Within the nascent RNA, the primary amine from aminoallyl-uridylate increases its coupling efficiency to the nascent RNA channel. However, an additional radius of cross-linking should be expected due to the allyl moiety. Cross-linking of the $\sim 10$-nt nascent RNA should enrich for peptides from residues $49-72$ from NS5B as well as from residues $21-43$ that correspond to the $\Delta 1$ loop that lies above peptide 49-72 (Fig. 3; Supplemental Fig. 2A). These results are consistent with those from the RCAP assay.
As an additional test to the nascent RNA exiting from the right side of the RdRp, a de novo initiation-defective RdRp mutant, m26-30, which retained the ability to elongate RNA in the presence of a primer-template duplex, was characterized (Chinnaswamy et al. 2008, 2010b). M26-30 was used to form a ternary complex and subjected to the RCAP assay. Peptides that contain residues $51-56$ and $66-74$ were observed in the complex with $5 \mathrm{P} / 12 \mathrm{~T}$. The same two peptides along with one that contains residues $73-81$ were observed in the ternary complex that contained $5 \mathrm{P} / 12 \mathrm{~T}$ and both ATP and UTP (Fig. 3; Supplemental Fig. 2B). Residues 73-81 lie on the back face of the RdRp and contain the same region that contacted the nascent RNA generated by $1 b \Delta 21$ (Fig. $3 \mathrm{~B})$. In summary, two versions of the $1 \mathrm{~b}$ HCV RdRp that are capable of elongative RNA synthesis identified that the nascent RNA exits to the right of the central cavity.

To further examine $1 \mathrm{~b} \Delta 21$ contact with the nascent RNA, we used positive-ion-mode mass spectrometry in an attempt to identify peptides that are not in contact with RNA (Steen and Jensen 2002). The negative charges of the RNA should bias against the RNA-contacting peptides once they are covalently linked with formaldehyde. To ensure that only peptides derived from NS5B that are in contact with the RNA were visualized, RNA-protein conjugates were purified by cyclo-addition before digestion with trypsin. Peptides derived from the polymerase in the presence of UTP reproducibly contained a peptide that corresponds to residues 66-74 (Fig. $4 \mathrm{~A})$. However, peptides released from tryptic digests of the ternary complex that formed in the presence of UTP and ATP did not contain single or multiply charged ions for residues 66-74 (Fig. 4B). These results suggest that this region of NS5B is in contact with the nascent RNA. Additionally,
A

\begin{tabular}{r|c|c|c|c}
\hline \multicolumn{1}{c|}{ AA\# } & 5P & 5P/12T & $\begin{array}{c}\text { 5P/12T+ } \\
\text { UTP }\end{array}$ & $\begin{array}{c}\text { SP/12T+ } \\
\text { UTP, ATP }\end{array}$ \\
\hline $1.49-56$ & & & $\checkmark$ & $\checkmark$ \\
$2.66-72$ & & & & $\checkmark$ \\
$115-120$ & $\checkmark$ & $\checkmark$ & $\checkmark$ & $\checkmark$ \\
$271-277$ & & $\checkmark$ & $\checkmark$ & $\checkmark$ \\
$* 346-379$ & & & & \\
$* 381-401$ & & & & \\
$* 402-422$ & & & & \\
$485-491$ & $\checkmark$ & $\checkmark$ & $\checkmark$ & $\checkmark$ \\
$499-503$ & $\checkmark$ & $\checkmark$ & $\checkmark$ & $\checkmark$ \\
$504-510$ & $\checkmark$ & $\checkmark$ & $\checkmark$ & $\checkmark$ \\
$3.511-517$ & $\checkmark$ & $\checkmark$ & $\checkmark$ & $\checkmark$ \\
\hline \multicolumn{5}{l}{}
\end{tabular}

B

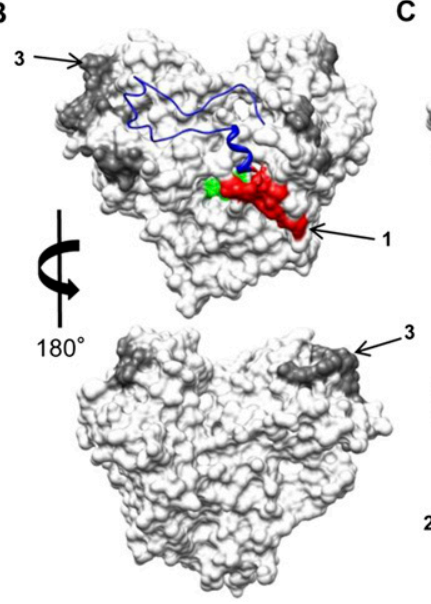

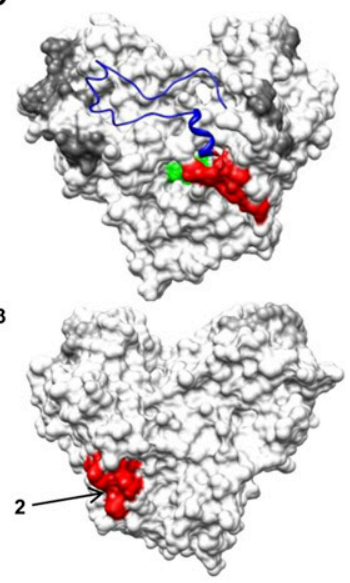

FIGURE 2. Identification of peptides associated with the nascent RNA by the RCAP assay. (A) Peptides identified in the RCAP assay performed with nascent RNAs synthesized in the presence of different nucleotides. Peptides were resolved by a Bruker Autoflex III MALDI-TOF mass spectrometer set in reflectron mode. The reactions were performed as described in Materials and Methods. Peak assignments to peptides within NS5B were based on theoretical digests that match calculated masses within $0.5 \mathrm{Da}$. (Red) Peptides within a region only identified during RNA synthesis; $\left(^{*}\right)$ peptides from the primer grip region that were not identified in any of the experimental setups. $(B, C)$ Molecular model of the peptides within NS5B found to contact RNA (PDB: 1QUV). (Gray) Peptides found to contact 5P or 5P/12T; (red) peptides present only with the ternary complex generated in the presence of UTP or UTP and ATP; (green) the active site of NS5B; (blue in the ribbon structure) the $\Delta 1$ loop. 
A

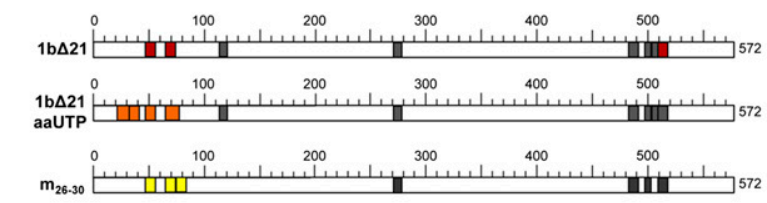

B

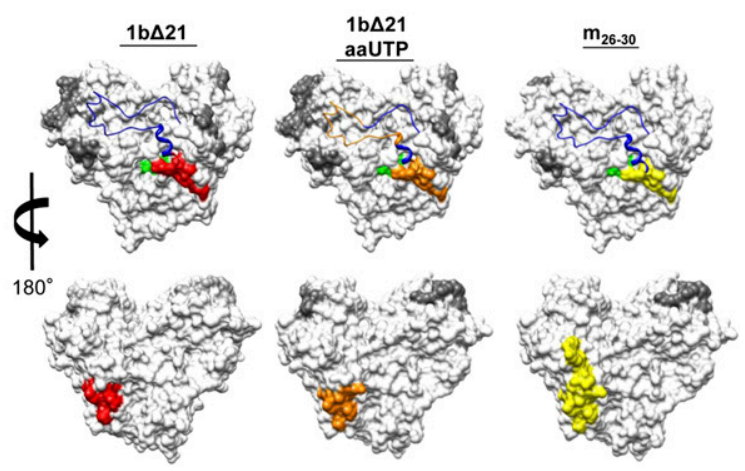

FIGURE 3. Mapping of the residues in the HCV RdRp that contact the nascent RNA. (A) Schematic representation of peptides identified in the RCAP assay variations. Colored regions represent peptides identified during RNA synthesis: (red) regions identified by the RCAP assay of $1 \mathrm{~b} \Delta 21$; (orange) regions identified during RNA synthesis using a nucleotide analog, aminoallyl-UTP (aaUTP); (yellow) regions identified within m26-30, an RdRp mutant defective in de novo initiation. Details regarding the peptide assignments can be found in Supplemental Figure 2. The reactions were performed as described in Materials and Methods. Peak assignments to peptides within NS5B were based on theoretical digests that match calculated masses within $0.5 \mathrm{Da}$. (B) Molecular model of the peptides within NS5B found to contact RNA (PDB: 1QUV). (Gray) Peptides found to contact 5P or $5 \mathrm{P} / 12 \mathrm{~T}$; ones present only with the ternary complex generated in the presence of UTP (red), UTP (orange), or ATP (yellow); (green) the active site of NS5B; (blue in the ribbon structure) the $\Delta 1$ loop.

peptides of residues $51-56$ and $66-72$ were absent in the ternary complex formed in the presence of UTP. Reactions performed with both ATP and UTP resulted in the lack of peptides corresponding to amino acids 66-74 and 70-81 (Fig. $4 \mathrm{C})$. These results are also in good agreement with those from the RCAP assay (Figs. 2, 3) in identifying residues that contact the nascent RNA.

\section{Mapping of the nascent RNA exit site using an amidination interference assay}

A fourth method was used to map the nascent RNAcontacting residues in $1 \mathrm{~b} \Delta 21$ independently. S-Methyl thioacetimidate (SMTA) can covalently modify surfaceexposed lysine side chains and the N-terminal amine without major perturbations in the protein structure (Janecki et al. 2005). A comparison of the sites of SMTA modification from peptides derived from an apoprotein to those generated by the protein-ligand complex will identify regions of the protein that are changed upon ligand binding. SMTAmodified lysine will be marked in two ways: (1) by a $41-\mathrm{Da}$ mass change and (2) by the loss of trypsin cleavage.
We assessed whether nascent RNA synthesis would result in the increased protection of specific lysines. In the absence of RNA, all except two of the surface-exposed lysines were observed to be amidinated in multiple experiments (Fig. 5A). In the presence of 5P/12T, amidination at lysines 81,211 , and 212 were decreased to background. In the presence of $5 \mathrm{P} / 12 \mathrm{~T}$, UTP, and ATP, only one additional lysine, K51, was protected from amidination. Notably, K51 lies within the peptides identified in the RCAP assay, as well as the peptide missing in the positive-ion-mode experiment (Figs. 2, 4). The assignments of the differentially amidinated peptide were confirmed by MS/MS fragmentation spectra (Supplemental Fig. 3). Altogether, four independent approaches identified the right side of the central cavity of the HCV RdRp to contact the nascent RNA. The region contains $\alpha$-helices $\mathrm{B}$ and $\mathrm{C}$ in residues $49-72$ and lies underneath the $\Delta 1$ loop in the fingers domain of NS5B (Bressanelli et al. 1999).

A

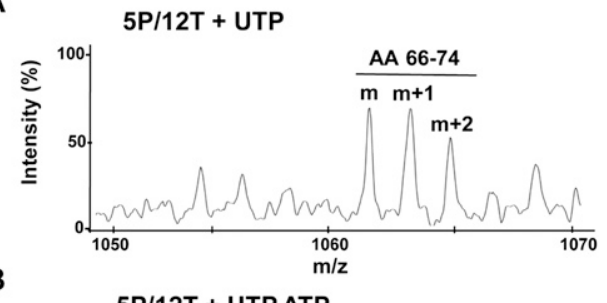

B

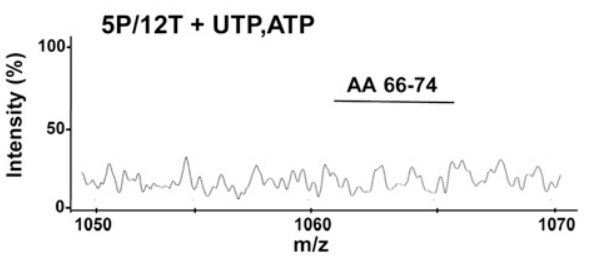

C

\begin{tabular}{c|c|c|c|c}
\hline AA \# & 5P & 5P/12T & $\begin{array}{c}\text { 5P/12T } \\
\text { +UTP }\end{array}$ & $\begin{array}{c}\text { 5P/12T } \\
\text { +UTP, ATP }\end{array}$ \\
\hline $115-120$ & $\mathrm{X}$ & $\mathrm{X}$ & $\mathrm{X}$ & $\mathrm{X}$ \\
$51-56$ & & & $\mathbf{X}$ & $\mathbf{X}$ \\
$338-345$ & $\mathrm{X}$ & $\mathrm{X}$ & $\mathrm{X}$ & $\mathrm{X}$ \\
$66-72$ & & & $\mathbf{X}$ & $\mathbf{X}$ \\
$338-345$ & $\mathrm{X}$ & $\mathrm{X}$ & $\mathrm{X}$ & $\mathrm{X}$ \\
$66-74$ & & & & $\mathbf{X}$ \\
$492-501$ & $\mathrm{X}$ & $\mathrm{X}$ & $\mathrm{X}$ & $\mathrm{X}$ \\
$492-501$ & & $\mathrm{X}$ & $\mathrm{X}$ & $\mathrm{X}$ \\
$70-81$ & & & & $\mathbf{X}$ \\
\hline
\end{tabular}

FIGURE 4. Analysis of the peptides from the RdRp ternary complex that are not cross-linked to the RNA. (A) MALDI-TOF mass spectra of a peptide detected in the presence of 5P/12T and UTP. The spectrum was generated using positive-mode ionization. (B) MALDITOF mass spectra of the same $\mathrm{m} / z$ region as in $A$ in the presence of $5 \mathrm{P} / 12 \mathrm{~T}$ and both UTP and ATP. The peptide corresponding to amino acids 66-72 is no longer detectable. (C) Table of peptides that are lost during RNA synthesis. (X) A peptide no longer detected in the mass spectra under the experimental setup indicated. Peptides no longer detected during RNA synthesis are in bold. 
A

\begin{tabular}{l|c|c|c}
\hline \multicolumn{1}{c|}{ AA \# } & $\boldsymbol{\phi}$ & 5P/12T & $\begin{array}{c}\text { 5P/12T + } \\
\text { ATP,UTP }\end{array}$ \\
\hline K20,69, 79, & & & \\
90100,106, & & + & + \\
$114,124,141$, & + & + & \\
$151,209,270$, & & & \\
$491,523,535$ & & - & - \\
K72 & - & ND & ND \\
K155 & ND & + & ND \\
K298 & + & ND & ND \\
K307, 533 & + & - & - \\
K81,211,212 & + & + & N/D \\
K50 & + & + \\
K51 ** \\
\hline \multicolumn{4}{|c}{ ** Protected only after RNA synthesis }
\end{tabular}

B

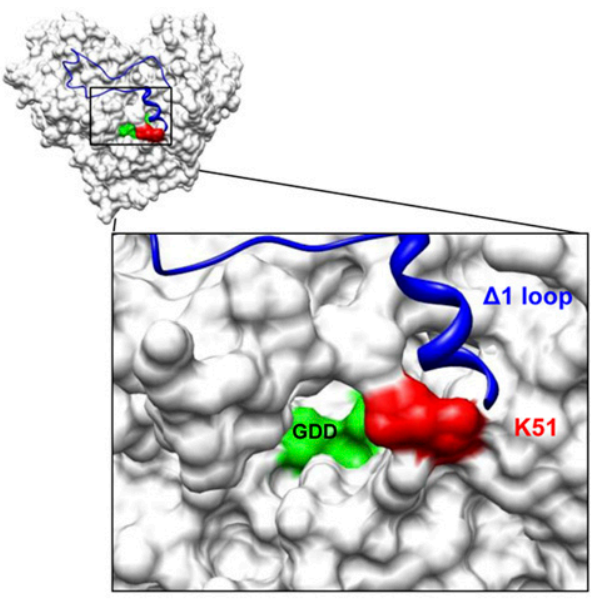

FIGURE 5. Mapping interactions in the RdRp ternary complex using an aminidation interference assay. (A) Lysines modified in the presence of $S$-methyl thioacetimidate (SMTA) as a function of RNA synthesis condition. Briefly, $0.3 \mu \mathrm{M} 1 \mathrm{~b} \Delta 21$ was added to a $50-\mu \mathrm{L}$ reaction containing $100 \mathrm{mM}$ HEPES, $4 \mathrm{mM} \mathrm{MgCl}_{2}, 12.5 \mathrm{mM}$ dithiothreitol, $0.5 \%$ Triton X-100 (v/v), and the RNAs and NTPs indicated. An equal volume of $200 \mathrm{mM}$ SMTA dissolved in the same buffer was added for $1 \mathrm{~h}$ to allow modification of all surface-exposed lysines. After exchanging the buffer with $100 \mathrm{mM} \mathrm{NH} \mathrm{NHCO}_{3}$, trypsin was added and it was incubated overnight at $37^{\circ} \mathrm{C}$. The peptides were then analyzed using a LTQ linear ion trap mass spectrometer (Thermo Scientific). (ND) No data were obtained for that residue. (B) Molecular models of NS5B that highlight K51, which is differentially protected during RNA synthesis. (Red) K51; (blue) the $\Delta 1$ loop; (green) the GDD active-site motif.

\section{Mutations in the nascent RNA channel can affect HCV replication}

Residues 49-71 contain several charged residues as well as a phenylalanine that could interact with the nascent RNA. To assess whether this sequence was conserved in the HCV genotypes, the sequences corresponding to residues 49-59 in the HCV genome database were analyzed. Ninety-eight percent of genotype $1 \mathrm{~b}$ HCV strains and $91 \%$ of all genotypes in the HCV database had the exact sequence. The most variable residue was L57 (Fig. 6A). The high degree of conservation suggests that this region is important for NS5B function.

Several mutations within the putative nascent RNA binding region of NS5B were generated and analyzed for defects in RNA synthesis in vitro and in the context of the replicon. The mutations represent our best guess concerning features within the putative nascent RNA channel that could affect interactions with RNA while retaining NS5B structure. The mutants were K5051Q (both lysines substituted with glutamines), F54A, L57W, and LQ5758NE (L57 substituted with asparagine and Q58 substituted with a glutamate) and were initially tested in the $1 \mathrm{~b} / \mathrm{Con} 1$ subgenomic replicon to assess for effects on HCV replication (Fig. 6B,C). Mutants K5051Q, F54A, and LQ5758NE showed significant reductions in the HCV replication-dependent colony formation assay (Fig. 6C). The same three mutants reduced HCV RNA as determined by qRT-PCR (Fig. 6D). Mutant L57W, the least conserved residue in the putative nascent RNA channel
(Fig. 6A), did not exhibit a defect in the HCV subgenomic replicon assay.

\section{Effects of mutation on properties of recombinant HCV RdRps}

Results from the subgenomic replicon suggest that the changes in residues 4959 could affect RNA-dependent RNA synthesis by the recombinant NS5B. Therefore, all four mutations were individually engineered into the recombinant protein $1 \mathrm{~b} \Delta 21$. All of the proteins were soluble (Fig. 7A). To determine whether the mutant proteins were affected for interaction with the template RNA, the anisotropy of a version of $12 \mathrm{~T}$ that contained a $5^{\prime}$ fluorescein was measured (Fig. 7B; Supplemental Fig. 4). $1 \mathrm{~b} \Delta 21$ had an affinity of $300 \mathrm{nM}$ with a standard error of $11 \mathrm{nM}$, and all mutant proteins had comparable affinity for the labeled 12T (Fig. 7B). These results suggest that these mutations did not significantly affect their ability to bind template RNA.

To examine whether the mutations affected RNA-dependent RNA synthesis, LE19 was used as a template. LE19 can report on the ability of the polymerase to extend from a primed template and to initiate de novo on the same template sequence (Ranjith-Kumar et al. 2002b). The mutant polymerases had different total levels of RNA synthesis, with K5051Q and LQ5758NE being less active for RNA synthesis than $1 \mathrm{~b} \Delta 21$, while F54A and L57W retained highly active RNA synthesis when both the de novoinitiated and the primer extension products were quantified (Fig. 7B). RNA synthesis by K5051Q, L57W, and LQ5758 approximately corresponded to RNA replication by the subgenomic HCV replicons. However, mutant F54A was defective in the replicons but retained robust activity as the recombinant protein. We do not know the reason for this discrepancy, but it is known that other viral proteins and/ or the environment within the cell will affect RNA synthesis by NS5B (Kang et al. 2009; Ranjith-Kumar et al. 2011).

\section{Characterization of the RdRp ternary complex}

All four of the mutant polymerases, including F54A, produced a lower ratio of the primer-extended products from LE19 than the de novo-initiated product $(p<0.05)$ (Fig. $7 C)$. The reduction in primer extension could indicate that the mutant RdRps have some defect in elongative RNA synthesis.

To examine this possibility, we first used the RCAP assay to separate the peptides generated from ternary complexes 
A

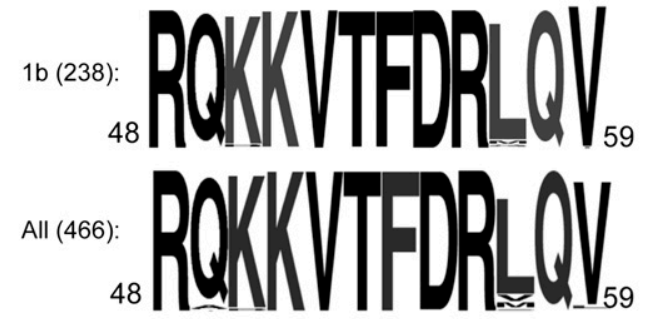

B

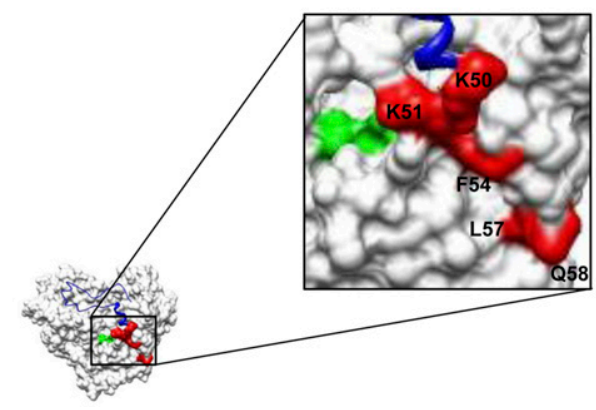

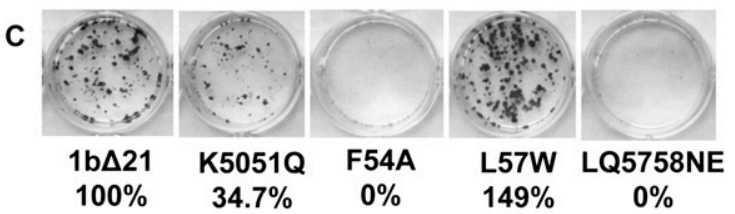

D

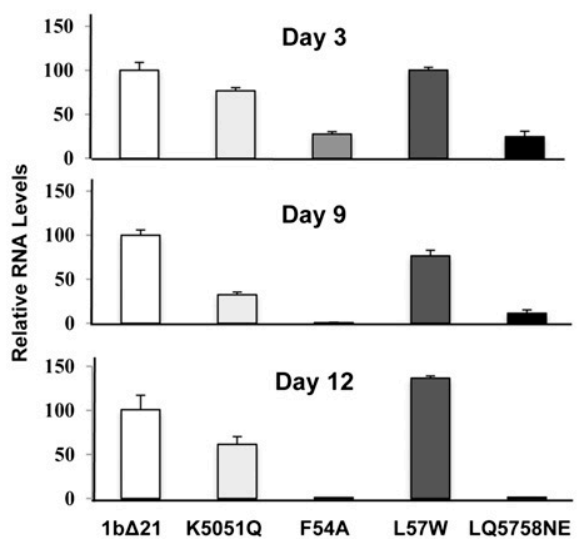

FIGURE 6. Nascent RNA channel mutants and their effect on replicon replication. (A) Sequence alignment of the region of NS5B found to contact nascent RNA. Alignments are of the $1 \mathrm{~b}$ genotype and for all genotypes deposited in the HCV database. (B) Location of mutated residues on the structure of NS5B. (Red) Mutated residues; (green) the GDD active site; (blue in the ribbon structure) the $\Delta 1$ loop. (C) Colony formation assay. One microgram of replicon RNA containing either wild type (WT) NS5B or mutant NS5B was electroporated into Huh7.5 cells and plated to assay for the presence of G418-resistant colonies as described in Materials and Methods. G418 was present in the medium at $0.5 \mathrm{mg} / \mathrm{mL}$ G418 (Invitrogen) and was stained by crystal violet after $3 \mathrm{wk}$. (D) Transient replication of replicon RNAs. Total RNA was extracted from replicon cells using TRIzol reagent (Invitrogen) at the days of post-transfection indicated, and viral RNAs were quantified by real-time RT-PCR. The percent change of each mutant was done in triplicate and compared with wild-type RNA levels.

generated from the wild-type (WT) and K5051Q RdRps along with $5 \mathrm{P} / 12 \mathrm{~T}$ in the presence of UTP and ATP (generating nascent RNAs of $10 \mathrm{nt}$ or longer) (Fig. 1). The peptides bound or unbound to the alkyn-labeled nascent RNA were analyzed according to the protocols diagrammed in Supplemental Figure 5A. With K5051Q, the loss of the lysines will prevent formaldehyde cross-linking to the RNA (Metz et al. 2004); however, if it retains binding to the nascent RNA, it should not be present in the unbound fraction. For the $1 \mathrm{~b} \Delta 21$ ternary complex, peptide $49-56$ was present in the fractions associated with the alkyn-labeled nascent RNA and absent in the unbound fraction (Supplemental Fig. 5B). With the ternary complex of mutant $\mathrm{K} 5051 \mathrm{Q}$, the glutamine substitutions altered the mass of peptide $49-56$ by only $0.072 \mathrm{Da}$, but the peptide was absent in the RNA-bound fraction and present in the unbound fraction (Supplemental Fig. 5C). This demonstrates that this region is directly involved in interacting with the nascent RNA, and a mutation would likely have an effect on its biochemical activity.

A defect in the contact with the nascent RNA channel should result in the RdRps exhibiting increased tendencies to release from their ternary complex. To test this directly, the polarization of $1 \mathrm{~b} \Delta 21$ and the mutant RdRps was determined with complexes formed with the fluoresceinlabeled $12 \mathrm{~T}$ and/or $5 \mathrm{P}$ and NTPs. The ability to form a ternary complex with $1 b \Delta 21$ resulted in a slight enhancement in fluorescence polarization. However, all four mutants either exhibited a reduction in polarization or remained unchanged (Fig. 8A). With the addition of UTP, or UTP and ATP, a reduction in the relative change in polarization was observed with the four mutant RdRps when compared with $1 \mathrm{~b} \Delta 21$. This suggests that the mutants form less stable ternary complexes when compared with $1 \mathrm{~b} \Delta 21$.

To further investigate the stability of the ternary complex with the four putative nascent RNA channel mutants, the polyanionic heparin was used to inhibit additional rounds of RNA synthesis from $12 \mathrm{~T}$ (Fig. 8B). Heparin acts as a template mimic to trap free polymerases after they release from the template (Walter et al. 1967). All of the RdRps preincubated with only $12 \mathrm{~T}$ were highly sensitive to heparin (Fig. 8C, left panel), indicating that the binary complex is highly dynamic. Preincubation with 5P/12T resulted in $1 \mathrm{~b} \Delta 21$ being significantly more resistant to heparin when compared with the four mutant polymerases (Fig. 8C, right panel). In fact, lower concentrations of heparin actually increased RNA synthesis from the $5 \mathrm{P} / 12 \mathrm{~T}$ complex from $1 \mathrm{~b} \Delta 21$, possibly due to the molecular crowding effect of the long heparin polymers. Similar results were seen in early studies on the effects of heparin on polymerase activity (Walter et al. 1967; Novello and Stirpe 1969). Taken together, these data show that mutations in the putative nascent RNA channel affected the stability of the ternary complex.

Finally, we reasoned that a reduction in the interactions between the mutant RdRps and the nascent RNA will be exacerbated when the template RNA contained modifications 

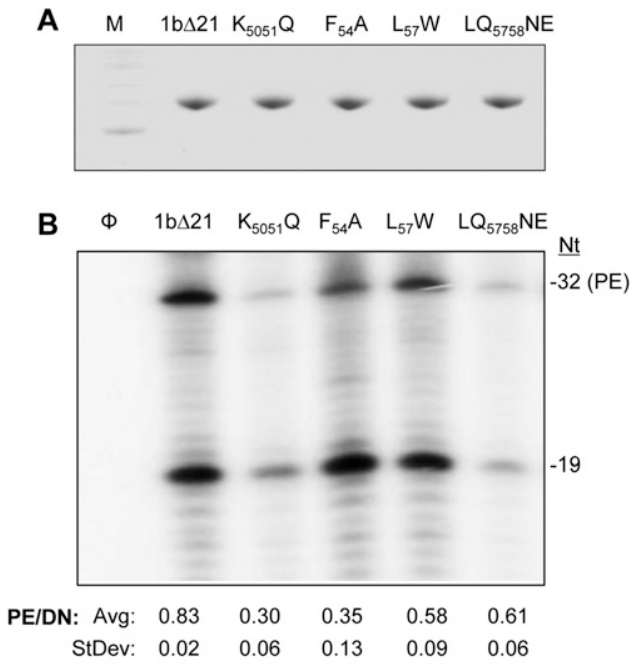

\begin{tabular}{ccc}
$\mathbf{C}$ & $\mathbf{K d}(\mathrm{nM})$ & $\mathbf{R}^{\mathbf{2}}$ \\
\cline { 2 - 3 } $\mathbf{\Delta 2 1}$ & $302.6( \pm 11)$ & 0.9970 \\
$\mathbf{K}_{5051} \mathbf{Q}$ & $297.7( \pm 33)$ & 0.9802 \\
$\mathbf{F}_{54} \mathbf{A}$ & $280.1( \pm 47)$ & 0.9932 \\
$\mathbf{L}_{57} \mathbf{W}$ & $287.8( \pm 21)$ & 0.9946 \\
$\mathbf{L Q}_{5758} \mathrm{NE}$ & $275.9( \pm 28)$ & 0.9897 \\
\hline
\end{tabular}

FIGURE 7. Biochemical characterization of the nascent RNA channel mutants. (A) Recombinant protein purification. The purified proteins were separated by SDS-PAGE ( $4 \%-12 \%$ polyacrylamide) and visualized by Coomassie Blue stain. (B) RNA synthesis using LE19 as the template RNA sequence. LE19 is capable of directing primerdependent (32-nt product) and primer-independent (de novo) RNA synthesis (Ranjith-Kumar et al. 2001). Larger species are products of template-switch RNA synthesis. Quantification of de novo and primer extension RNA synthesis by $1 \mathrm{~b} \Delta 21$ NS5B and mutant proteins are below the gel. Averages and standard errors were from five independent experiments. $(C)$ Affinities of RdRp and mutants to $12 \mathrm{~T}$ as determined by fluorescence anisotropy experiments. $12 \mathrm{~T}$, at a final concentration of $0.2 \mu \mathrm{M}$, was resuspended in a buffer containing 50 $\mathrm{mM}$ HEPES (pH 7.5), $5 \mathrm{mM} \mathrm{MgCl}_{2}, 0.002 \%$ Tween 20 , and $50 \mathrm{mM}$ $\mathrm{NaCl}$; RdRp or the nascent RNA channel mutant was titrated in. Sixty anisotropy values were taken after the RdRp was allowed to equilibrate for $1 \mathrm{~min}$. The data were fitted into the Hill equation using KaleidaGraph software.

that could further destabilize the ternary complex. Modifications at specific 2 -hydroxyls were found to affect the length of the RNA products synthesized by the replicases of two plant RNA viruses (brome mosaic virus and cowpea chlorotic mottle virus) and the recombinant RdRp from the flavivirus bovine viral diarrhea virus (Kim et al. 2000; Tayon et al. 2001). Therefore, a series of templates derived from $12 \mathrm{~T}$ with pairs of consecutive $2^{\prime}$-deoxyribose modifications was synthesized and tested for RNA synthesis under standard conditions (Fig. 9A).

RNA synthesis by $1 \mathrm{~b} \Delta 21$ from the set of modified templates was initially determined after a 2-min incubation. All of the deoxyribose $\left(2^{\prime} \mathrm{H}\right)$-containing templates had discernible effects on RNA synthesis by $1 \mathrm{~b} \Delta 21$ when compared with the unmodified control, 12T. Based on the sizes of the products relative to molecular weight markers and the availability of NTPs, the three predominant products observed had a terminal nucleotide added to the template $(T+1)$ of $13 \mathrm{nt}$, a de novo-initiated 12-nt product $(N)$, and a prematurely terminated product of $11 \mathrm{nt}(\mathrm{N}-1)$ (Fig. 9B, upper image). Notably, $2^{\prime} \mathrm{H}$ substitutions at the positions +6 and +7 in the template had the most dramatic defect, as determined by the amount of $N$-length product. In the presence of the nascent RNA mimic 5P, the $N$-length product increased in abundance relative to the $N-1$ product (Fig. 9B, bottom gel image). Notably, even abundant $N$-length product was observed with $2^{\prime} \mathrm{H}$ substitutions at the $+6,+7$ positions (Fig. 9B). This is likely due to an increase in stabilization of the ternary complex in the presence of the nascent RNA mimic before RNA synthesis.

The ratio of the products made by the four mutant polymerases in the presence of $5 \mathrm{P}$ and in its absence was determined in five independent experiments, and the results are summarized in Figure 9C. All four mutant polymerases exhibited a significantly reduced ratio of $N$ to $N-1$ product compared with $1 \mathrm{~b} \Delta 21$, indicating that $5 \mathrm{P}$ had less of a stabilizing effect on RNA synthesis by the mutants when compared with $1 \mathrm{~b} \Delta 21$ (Fig. 9C). The mutants also exhibited reproducible differences in the products made from the different templates. In the presence of 5P, mutants F54A, L57W, and LQ5758NE had decreased products with the templates containing $+2,+3$ and $+9,+10$ substitutions, while mutant K5051Q exhibited larger defects in templates containing deoxyribose modifications from positions $+4,+5$ to $+10,+11$, but was unaffected by $2^{\prime} \mathrm{H}$ at the $+2,+3$ positions (Fig. 9C). These results confirm that the mutations in the putative nascent RNA channel had defects in product synthesis. Furthermore, the four recombinant proteins had distinguishable differences in RNA synthesis with the four mutant polymerases.

\section{DISCUSSION}

In this study, we mapped a region of the HCV RdRp that contacts nascent RNA using a combination of mass spectrometry-based approaches. Four mutations were made in the putative nascent RNA exit channel, and all four mutations exhibited defects in elongative RNA synthesis in biochemical assays, while three were also debilitated for HCV subgenomic RNA synthesis in Huh7.5 cells.

The nascent RNA channel in NS5B was identified using multiple independent approaches. The RCAP assay with an alkyn-labeled primer captured peptides derived from the region immediately below the $\Delta 1$ loop of the HCV NS5B protein. The same region was identified using a modified nucleotide, as well as a de novo initiation-defective $\mathrm{RdRp}$ mutant. The corresponding peptide from the K5051Q mutant did not bind the nascent RNA. An amidination interference assay showed that K51 was protected from modification only during RNA synthesis. Previous studies have identified that this part of the RdRp contacts RNA, 


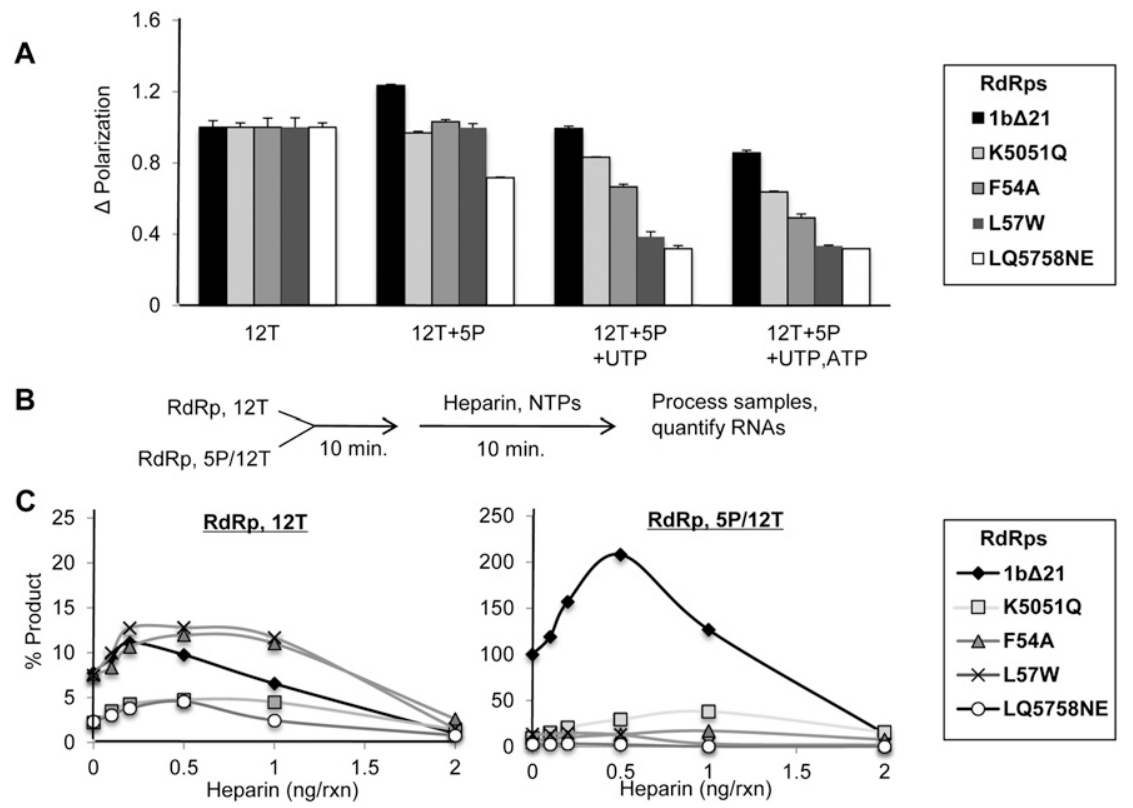

FIGURE 8. RNA synthesis by the putative nascent RNA channel mutants in the presence of a nascent RNA mimic. (A) Change in fluorescence polarization while walking RdRps down 12T. Plotted is the change in fluorescence polarization under the conditions listed. All values are normalized to $\mathrm{RdRp}+12 \mathrm{~T}$. $(B)$ Outline of the heparin titration experiment. RdRps were preincubated with either the $12 \mathrm{~T}$ template alone or in the presence of the $5 \mathrm{P}$ primer. Heparin along with nucleotides were then added, and RNA synthesis was quantified by radiolabel incorporation. $(C)$ The effect of heparin on RNA synthesis in the presence and absence of the 5P nascent RNA mimic used in the RCAP assay. Plotted is the relative abundance of RNA synthesized in the presence of different concentrations of heparin as indicated. In the presence of the $12 \mathrm{~T}$ template alone, $1 \mathrm{~b} \Delta 21$ and the nascent RNA channel mutants showed discernable amounts of RNA synthesis (left panel). However, in the presence of $12 \mathrm{~T} / 5 \mathrm{P}$, RNA synthesis by $1 \mathrm{~b} \Delta 21$ is significantly enhanced (right panel). This enhancement is not seen among any of the nascent RNA channel mutants.

but those studies were done in the absence of RNA synthesis and using longer templates (Kim et al. 2005; Deval et al. 2007).

Structural comparison of the HCV RdRp to other related viral RdRps such as HIV-1 have identified the primer-grip motif that is thought to interact with the nascent primer strand at the juncture between the palm and the fingers domain (Bressanelli et al. 1999; Liu et al. 2008, 2011; Leung et al. 2011). Notably, peptides from the primer grip were not identified by any of the methods used in this work. However, the primer grip may contact the RdRp primarily through electrostatic interactions (Tao et al. 2002) and, hence, was not as conducive to cross-linking that required the bases in the primer-template duplex. Should the primergrip interaction constrain the 5 -terminal portion of the RdRp-nascent RNA interaction, our mapping result on the portion of the RdRp that contacts the nascent RNA contacts would require that the RNA extend toward the base of the $\Delta 1$ loop. The distance of initiation GTP to K51, as determined from the structure of Harrus et al. (2010) (PDB: 2X13) in the RdRp, is $\sim 16 \AA$, which is sufficient to accommodate an RNA duplex of $\sim 6 \mathrm{nt}$ assuming that the rise between base pairs in an A-form RNA duplex is $\sim 2.6 \AA$. In fact, an A-form RNA helix of $\sim 6$ bp has sufficient pitch to contact the primergrip region and contact residue K51. A model for the path of the nascent RNAtemplate duplex is shown in Figure 10.

K51 has been previously hypothesized to be part of the rNTP channel (Schuwirth et al. 2005). While our mapping of the nascent RNA contact site seems initially to be incompatible with the traffic of rNTPs to the active site, it is also possible that the rNTPs may enter the active site in closer proximity to the ternary complex than previously thought. RdRps have a slower rate of RNA synthesis when compared with other template-dependent polymerases (Tomei et al. 2000; Adelman et al. 2002), possibly due to more constrained diffusion of rNTPs to the active site.

Only with a fully extended nascent RNA of $\sim 10$ nt was the RCAP assay able to purify peptides on the opposite face of the RdRp. These results suggest that the nascent RNA, in the absence of the other replicase subunits, could wrap around the RdRp as it grows in length. Whether this interaction will take place within the membrane-embedded replicase complex remains to be determined. Previous studies have shown that NS5B transitions from a closed, de novo initiation-competent conformation to an open conformation upon its transition to elongation, after synthesis of $\sim 7-8 \mathrm{nt}$ (Chinnaswamy et al. 2008; Chinnaswamy et al. 2010b). Because of this, it cannot be ruled out that this transition leads to a conformation that would allow this region to come into contact with the nascent RNA without the need to wrap around to the other side of the polymerase. Even as such, this would imply that the nascent RNA exits the polymerase beneath the $\Delta 1$ loop at the right side of the central cavity.

Substitutions K5051Q, F54A, and L5758NE exhibited defects in the HCV subgenomic RNA replication as well as contact with the nascent RNA in biochemical assays. L57W exhibited a defect in nascent RNA binding as determined by the RNA synthesis assays in vitro, but it was not apparently detrimental to subgenomic replicon replication (Figs. $6 \mathrm{~B}, 7 \mathrm{~B})$. We do not have a suitable explanation for this discrepancy, but can only speculate that lack of cellular factors or the presence of other nonstructural proteins could have exacerbated the defect of the L57W mutation in vitro.

The in vitro RNA synthesis reactions with the $2^{\prime}$-deoxy substituted templates also provide information concerning the HCV RdRp elongative complex. Two results are 
A

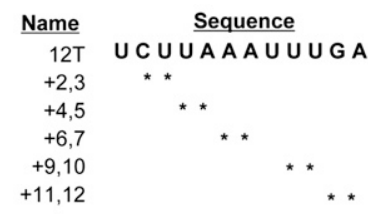

B

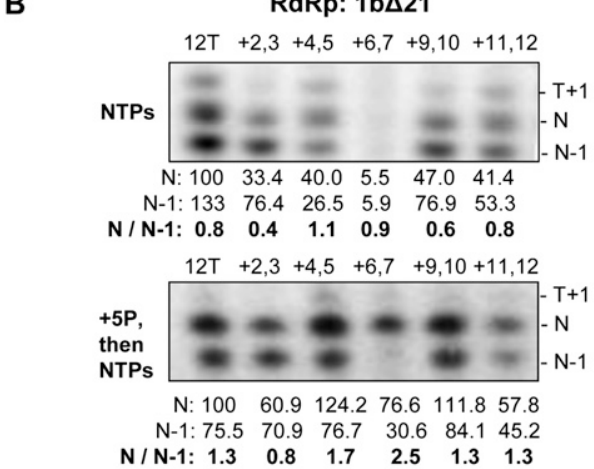

C

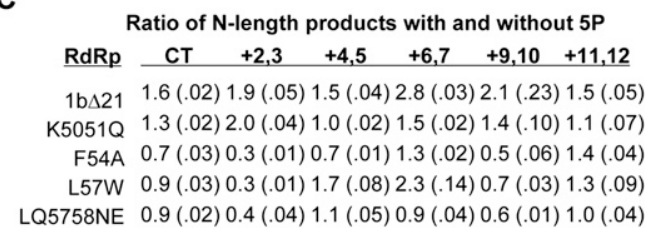

FIGURE 9. Effects of $2^{\prime}$-deoxyribose modification on RNA-dependent RNA synthesis by $1 \mathrm{~b} \Delta 21$ and the putative nascent RNA mutants. (A) Sequence of RNAs used to investigate N-length RNA synthesis. $\left({ }^{*}\right)$ The absence of a $2^{\prime}$-hydroxyl at the positions indicated. (B) Autoradiogram of RNA synthesis by wild-type $1 \mathrm{~b} \Delta 21$ NS5B in the presence and absence of $5 \mathrm{P}$ on the templates indicated. $(\mathrm{T}+1)$ The band corresponding to terminal nucleotide addition; $(\mathrm{N})$ the fulllength RNA product; $(\mathrm{N}-1)$ a prematurely terminated product. Below the gels are quantifications of RNA synthesis by $1 \mathrm{~b} \Delta 21$ NS5B normalized to 12T's N-length product. Ratios of $\mathrm{N} /(\mathrm{N}-1)$ are taken to represent the relative amount of N-length synthesis. (C) Average of the ratios of products formed with and without 5P. The products are equal to the length of the template $(\mathrm{N}), 1 \mathrm{nt}$ longer $(\mathrm{N}+1)$ or shorter $(\mathrm{N}-1)$, as indicated. The range for one standard error is shown in parentheses. These values were calculated from five independent experiments that had each sample assayed in triplicate per experiment.

particularly intriguing. First, $2^{\prime}$-deoxy modifications at +6 and +7 had the most dramatic effect on RNA synthesis in the absence of a preformed nascent RNA. Since this length corresponds to the bite size of the RdRp (Kao et al. 2000; Deval et al. 2007), it may be that contacts at these residues are especially critical for translocation of the RdRp to downstream sequences in the template. Additionally, the stability of the ternary complex is reduced for all nascent RNA channel mutants tested, as shown by a greater change in polarization while walking the RdRp down $12 \mathrm{~T}$ (Fig. 8A), and by an increased sensitivity to heparin (Fig. 8B,C). This shows that RdRp contacts with the nascent RNA enhance the stability of the ternary complex, and every mutant tested has defective contacts with the nascent RNA. Finally, we note that the ratios of the products formed without and with $5 \mathrm{P}$ differed with the four polymerases. For example, mutant L57W produced high levels of products in the presence of $5 \mathrm{P}$ with the $+6,+7$ template in a manner similar to $1 \mathrm{~b} \Delta 21$, while mutants K5051Q, F54A, and LQ7558NE all had higher levels of product synthesis in the presence of $5 \mathrm{P}$ with other members of the template series. These results suggest that changes in the template channel may affect how the RdRp contacts the template RNA.

Interaction between the T7 RNA polymerase and nascent RNA has been documented to regulate several properties of RNA synthesis, including processive elongation and nucleotide misincorporation (Macdonald et al. 1993; Lyakhov et al. 1998; Temiakov et al. 2000; Toulokhonov et al. 2001; Durniak et al. 2008). We expect that our proposed location of the nascent RNA channel in the HCV RdRp should affect HCV genome replication and could be useful for studies of polymerase error and RNA recombination in cells. Finally, our biochemical results make several predictions concerning the HCV RdRp ternary complex that should fuel additional experimentation on an important aspect of viral RNAdependent RNA synthesis.

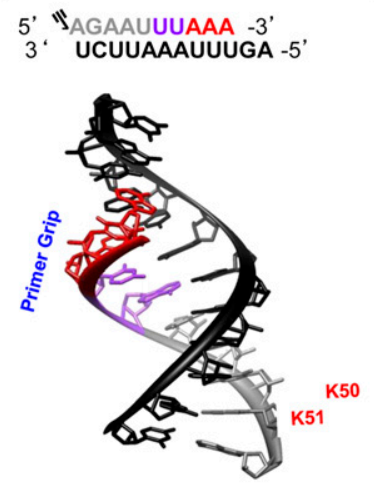

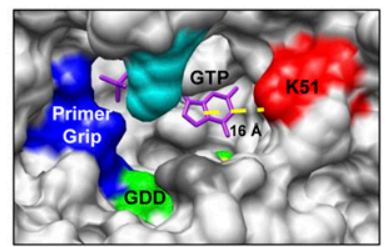

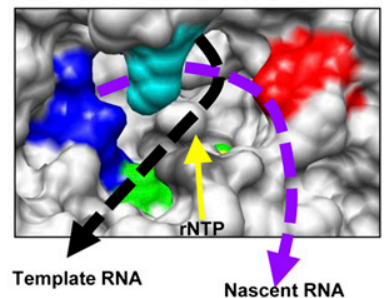

FIGURE 10. A model for the paths of the nascent and template RNAs as they exit the HCV RdRp. (A) Schematic and structure of 5P and $12 \mathrm{~T}$ relative to the primer grip and residues $\mathrm{K} 50$ and $\mathrm{K} 51$. The structure shown is an A-form RNA helix, trimmed to match the size of 12T and 5P (PDB: 1RNA). (Gray) 5P; (black) 12T; (purple and red residues) the walking of the polymerase. ( $B$, upper panel) Regions and structural features within NS5B to contact the nascent RNA. The location of the initiation GTP was used to denote the position of the first nucleotide that could form the nascent RNA. (Yellow sphere) The $\mathrm{Mg}^{2+}$ ion that coordinates the GTP to the GDD active site (green). (Red) Residue K51 that forms the beginning of the nascent RNA channel. The distance between $\mathrm{C} 5$ of the guanine to the terminal $\varepsilon$-amino atom of $\mathrm{K} 51$ is shown below the yellow dashed line. $(B$, lower panel) The proposed paths of the nascent and template RNA. The models used the coordinates in the polymerase-GTP complex of Harrus et al. (2010) (PDB: 2XI3). The figures were drawn with the Chimera program (UCSF, San Francisco) (Pettersen et al. 2004), and labels and features within the polymerase were added using Microsoft PowerPoint. 


\section{MATERIALS AND METHODS}

\section{Protein expression and purification}

For protein expression, wild-type and mutant HCV NS5B protein from the $1 \mathrm{~b}$ Conl strain without the C-terminal membraneanchoring residues $(\Delta 21)$ was expressed with a C-terminal $\mathrm{His}_{6}$ tag in Escherichia coli. Recombinant protein was purified through a Talon cobalt affinity column (Invitrogen) as previously described by Chinnaswamy et al. (2008). However, a nickel-NTA agarose column rather than a MonoS ion exchange resin was used to further purify $1 \mathrm{~b} \Delta 21$ and its derivatives (Invitrogen). The purified proteins were dialyzed and stored in $50 \mathrm{mM}$ Tris ( $\mathrm{pH} 7.5), 400$ $\mathrm{mM} \mathrm{NaCl}, 5 \mathrm{mM} \beta$-mercaptoethanol, and $10 \%(\mathrm{v} / \mathrm{v})$ glycerol at $-80^{\circ} \mathrm{C}$. Protein concentrations were determined by measuring the absorbance at $280 \mathrm{~nm}$, confirmed by SDS-PAGE stained with Coomassie Blue, and comparing the band intensity to bovine serum albumin of known quantity.

\section{Oligonucleotides, site-directed mutagenesis, and DNA sequencing}

Oligonucleotides, including those with chemical modifications, were synthesized by Integrated DNA Technologies. Mutations in the plasmid expressing $1 \mathrm{~b} \Delta 21$ were introduced using the QuikChange site-directed mutagenesis kit (Agilent Technologies). The complete open reading frame was sequenced to confirm the presence of directed mutation and absence of unintended mutations.

\section{Reversible cross-linking-peptide fingerprinting analysis (RCAP)}

NHS-agarose resin (Sigma-Aldrich) was coupled to azide-PEG4amine (Click Chemistry Tools, Inc.) to affinity-purify alkyn-labeled RNAs. The coupling reaction was performed in $0.1 \mathrm{M}$ sodium tetraborate ( $\mathrm{pH} 8.5$ ) and quenched by the addition of glycine to $1 \mathrm{M}$ final concentration. A typical RCAP assay consists of a $200-\mu \mathrm{L}$ reaction containing $100 \mathrm{mM}$ HEPES, $4 \mathrm{mM} \mathrm{MgCl}_{2}, 12.5 \mathrm{mM}$ dithiothreitol, $0.5 \%$ Triton X-100 (v/v), and $0.3 \mu \mathrm{M} 1 \mathrm{~b} \Delta 21$ that had been preincubated for $15 \mathrm{~min}$ in the presence of the RNAs and NTPs, where appropriate. Formaldehyde was then added to a final concentration of $0.1 \%(\mathrm{v} / \mathrm{v})$ for 10 min to cross-link the RNAprotein complexes followed by the addition of glycine to a final concentration of $0.2 \mathrm{M}$ to quench the cross-linking reaction. After 5 min, sequencing-grade trypsin (Promega) was added at 1:50 (w/w) in $100 \mathrm{mM} \mathrm{NH}_{4} \mathrm{HCO}_{3}(\mathrm{pH} 7.8)$, and the reaction was incubated overnight at $37^{\circ} \mathrm{C}$. Cyclo-addition of the alkyn-labeled RNA to the azide-containing resin was induced by the addition of $1 \mathrm{mM} \mathrm{CuSO}_{4}$ and $1 \mathrm{mM}$ TCEP for $1 \mathrm{~h}$. Unbound materials were washed away with three 1-mL washes of a buffer containing $20 \mathrm{mM}$ HEPES (pH 7.5), 1 $\mathrm{M} \mathrm{NaCl}, 1 \mathrm{mM}$ EDTA, and $1 \mathrm{mM}$ dithiothreitol. RNA-peptide conjugates were then reversed by incubating the samples for $1 \mathrm{~h}$ at $70^{\circ} \mathrm{C}$ in a buffer containing $50 \mathrm{mM}$ Tris ( $\left.\mathrm{pH} 7.5\right), 200 \mathrm{mM} \mathrm{NaCl}$, and $0.1 \%$ trifluoroacetic acid. The samples were centrifuged at $3000 \mathrm{~g}$ for $5 \mathrm{~min}$, and the supernatants containing the peptides were passed through a Ziptip column (Millipore). The bound peptides were eluted in $2.5 \mu \mathrm{L}$ of $70 \%$ acetonitrile and $0.1 \%$ trifluoroacetic acid and analyzed by MALDI-TOF (Bruker Autoflex III; Agilent Technologies) in positive-ion mode. Assigned peaks all corresponded to within $0.5 \mathrm{Da}$ of the theoretical masses of peptides from $1 \mathrm{~b} \Delta 21$.

\section{Amidination protection assay}

Differential modification of surface-exposed lysines was analyzed as described previously (Janecki et al. 2005). Briefly, $1 \mathrm{~b} \Delta 21$ (0.3 $\mu \mathrm{M})$ was added to a $50-\mu \mathrm{L}$ reaction containing $100 \mathrm{mM}$ HEPES, 4 $\mathrm{mM} \mathrm{MgCl}_{2}, 12.5 \mathrm{mM}$ dithiothreitol, $0.5 \%$ Triton X-100 (v/v), and preincubated for $15 \mathrm{~min}$ in the presence of the RNAs and NTPs indicated. An equal volume of $200 \mathrm{mM} S$-methyl thioacetimidate (SMTA) dissolved in the same buffer was added for $1 \mathrm{~h}$. After exchanging the buffer with $100 \mathrm{mM} \mathrm{NH}_{4} \mathrm{HCO}_{3}$, trypsin was added at a ratio of 1:50 (w/w) of the polymerase and incubated overnight at $37^{\circ} \mathrm{C}$. The samples were stored at $4^{\circ} \mathrm{C}$ before analysis using an LTQ linear ion trap mass spectrometer (Thermo Scientific). The tryptic digests were injected onto the C18 column (Waters NonaAcquity UPLC column: $100 \mu \mathrm{m} \times 100 \mathrm{~mm}, 1.7 \mu \mathrm{m}, \mathrm{BEH} 130$ C18) and eluted with a linear gradient of $1 \%-45 \%$ acetonitrile (in water with $0.1 \% \mathrm{FA}$ ) developed over $90 \mathrm{~min}$ at room temperature. The flow rate was $500 \mathrm{~nL} / \mathrm{min}$, and effluent was electro-sprayed into the LTQ mass spectrometer. MS/MS spectra were obtained by collision-induced dissociation.

A database search was performed using both Sequest and $\mathrm{X}$ !Tandem algorithms against the HCV protein sequence database from NCBI. Molecular modeling used the crystal structure of the 1b NS5B (Protein Data Bank code 1QUV) and the Chimera program (Pettersen et al. 2004).

\section{HCV subgenomic replicon assay}

EcoRI-SpeI restriction fragments containing a portion of the NS5A and the intact NS5B coding sequence of the 1b/Con1 replicon pFKI389/NS3-3'/WT (Lohmann et al. 1999) were subcloned into pCR-Blunt II TOPO (Invitrogen) for site-directed mutagenesis. The restriction fragment was used to replace the comparable sequence in pFKI389/NS3-3'/WT to generate the mutant replicons. ScaI-linearized plasmids purified by a QIAGEN column were used for in vitro transcription using the AmpliScribe T7-Flash Transcription Kit (Epicentre Technologies).

Huh7.5 cells were maintained in Dulbecco's modified Eagle's medium supplemented with $10 \%$ fetal bovine serum, 100 units of penicillin-streptomycin/mL, and $0.1 \mathrm{mM}$ nonessential amino acids. Trypsin-liberated Huh7.5 cells were washed twice with ice-cold Cytomix ( $120 \mathrm{mM} \mathrm{KCl} ; 0.15 \mathrm{mM} \mathrm{CaCl}, 10 \mathrm{mM} \mathrm{K}_{2} \mathrm{HPO}_{4} / \mathrm{KH}_{2} \mathrm{PO}_{4}$, $25 \mathrm{mM}$ HEPES, $2 \mathrm{mM}$ EGTA, $5 \mathrm{mM} \mathrm{MgCl}_{2}$, at $\mathrm{pH} \mathrm{7.6)}$ and suspended at $1 \times 10^{7}$ cells $/ \mathrm{mL}$ in ice-cold Cytomix for electroporation. Two hundred microliters of the cell suspension, $5 \mu \mathrm{g}$ of HCV replicon RNA, and $5 \mu \mathrm{g}$ of carrier RNA (total RNA extracted from naive Huh7.5 cells) were pulsed at $270 \mathrm{~V}, 96 \mathrm{mF}$ in a electroporation cuvette with a 2-mm gap (Bio-Rad Gene-pulser). The cells were allowed to recover for $10 \mathrm{~min}$ at room temperature before dilution in complete medium.

The colony formation assay used 1/10 of the electroporated cells seeded in the first well of a 12-well plate, followed by a twofold serial dilution of the cells into growth medium added to the remaining wells. G418 ( $0.5 \mathrm{mg} / \mathrm{mL}$; Invitrogen $)$ was added to culture media $24 \mathrm{~h}$ after electroporation. The selective medium was replaced every $3 \mathrm{~d}$ for $3 \mathrm{wk}$. Replicon-harboring colonies were stained with crystal violet, to allow enumeration of colony formation per microgram of HCV replicon RNA.

Real-time RT-PCR used total RNA extracted from Huh7.5 cells electroporated with the replicon RNAs as described above. 
First-strand cDNA synthesis used $1 \mu \mathrm{g}$ of total RNA extracted using the TRIzol reagent (Invitrogen) along with M-MulV (New England Biolabs) and $4 \mu \mathrm{M}$ a randomized 9-nt primer mix. RTPCR used the Bio-Rad IQTM SYBR Green kit (Bio-Rad), and the primers used were HCV $5^{\prime}$-UTRsense (5'-AGCCATGGCGT TAGTATGAGTGTC-3') and $5^{\prime}$-UTRanti (5'-ACAAGGCCTTT CGCGACCCAAC- $\left.3^{\prime}\right)$. The message for GAPDH was detected as an internal control using the sense and antisense oligonucleotides (5'-GAGTCAACGGATTTGGTCGT-3' and 5'-TGGGAT TTCCATTGATGACA-3', respectively). All reaction mixtures were heated for $10 \mathrm{~min}$ to $95^{\circ} \mathrm{C}$, followed by 40 cycles of PCR for $15 \mathrm{sec}$ at $95^{\circ} \mathrm{C}, 20 \mathrm{sec}$ at $55^{\circ} \mathrm{C}$, and $30 \mathrm{sec}$ at $72^{\circ} \mathrm{C}$. The percent change of each mutant was compared with wild type as previously described (Livak and Schmittgen 2001).

\section{Fluorescence spectroscopy}

Fluorescence measurements were made using a PerkinElmer luminescence spectrometer LS50B luminescence spectrometer and a cuvette with an optical path length of $0.4 \mathrm{~cm}$. Equilibrium anisotropy or polarization measurements were taken of a fluorescein-labeled $12 \mathrm{~T}$ $(0.2 \mu \mathrm{M}$ final concentration) in binding buffer (50 mM HEPES at $\mathrm{pH}$ 7.5, $5 \mathrm{mM} \mathrm{MgCl}_{2}, 0.002 \%$ Tween 20 , and $50 \mathrm{mM} \mathrm{NaCl}$ ). The integration time of $1 \mathrm{sec}$ and a slit width of $5 \mathrm{~nm}$ were used throughout the measurements. Titrations for anisotropy measurements were performed by successive addition of $1 \mathrm{~b} \Delta 21$ with constant stirring. Polarization measurements were taken with $1 \mathrm{~b} \Delta 21$ at a constant concentration of $300 \mathrm{nM}$. All values collected were averaged from 60 measurements after each sample had equilibrated for $1 \mathrm{~min}$.

Binding data were analyzed by nonlinear least-squares fitting using KaleidaGraph software (Synergy Software). The equilibrium dissociation constants $\left(K_{\mathrm{d}}\right)$ were fitted into the Hill equation $\left(\Delta A=B_{\max } x^{n} /\left[x^{n}+K_{\mathrm{d}}{ }^{n}\right]\right)$ as a binding model. $\Delta A$ is the value of anisotropy change by the ligand binding, $B_{\max }$ is the value of maximum anisotropy change, $x$ is the total concentration of the input ligand, and $n$ is the Hill coefficient.

\section{RNA synthesis assay}

Standard RdRp assays consisted of $2.5 \mathrm{pmol}$ of template RNA, and $0.08 \mu \mathrm{M}$ NS5B in a $20-\mu \mathrm{L}$ reaction containing $20 \mathrm{mM}$ sodium glutamate ( $\mathrm{pH} 8.2$ ), $4 \mathrm{mM} \mathrm{MgCl} 2,1 \mathrm{mM} \mathrm{MnCl}_{2}, 12.5$ $\mathrm{mM}$ dithiothreitol, $0.5 \%$ Triton $\mathrm{X}-100(\mathrm{v} / \mathrm{v})$, and $50 \mathrm{mM}$ the NTPs indicated. Where present, radiolabeled NTPs were used at a final concentration of $250 \mathrm{nM}$. Aminoallyl-UTP was from Thermo Scientific. Heparin inhibition assays (Sigma-Aldrich) used a template RNA concentration of 60 pmol per reaction, an amount determined empirically to be twice the half-maximal concentration needed to saturate RNA synthesis. The reactions were incubated at $30^{\circ} \mathrm{C}$ for the amount of time indicated, and terminated by the addition of formamide-containing loading buffer. RNA products were loaded directly onto a $20 \%$ polyacrylamide gel containing $7.5 \mathrm{M}$ urea and electrophoresed at 400 $\mathrm{V}$ for $4 \mathrm{~h}$. RNA synthesis was visualized and quantitated by the amount of $\left[\alpha-{ }^{32} \mathrm{P}\right] \mathrm{CTP}$ (MP Biomedicals, LLC) incorporated in RdRp products using a PhosphorImager (Typhoon 9210; Amersham Biosciences). All data were from a minimum of three independent experiments.

\section{SUPPLEMENTAL MATERIAL}

Supplemental material is available for this article.

\section{ACKNOWLEDGMENTS}

We thank C.T. Ranjith-Kumar and Hui Cai for helpful discussions. This work was supported by grant 1RO1AI073335 from the NIAID to C.K.

Received December 12, 2011; accepted May 30, 2012.

\section{REFERENCES}

Adelman K, La Porta A, Santangelo TJ, Lis JT, Roberts JW, Wang MD. 2002. Single molecule analysis of RNA polymerase elongation reveals uniform kinetic behavior. Proc Natl Acad Sci 99: 1353813543.

Appel N, Schaller T, Penin F, Bartenschlager R. 2006. From structure to function: New insights into hepatitis $\mathrm{C}$ virus RNA replication. J Biol Chem 281: 9833-9836.

Biswal BK, Cherney MM, Wang M, Chan L, Yannopoulos CG, Bilimoria D, Nicolas O, Bedard J, James MN. 2005. Crystal structures of the RNA-dependent RNA polymerase genotype 2a of hepatitis $\mathrm{C}$ virus reveal two conformations and suggest mechanisms of inhibition by non-nucleoside inhibitors. J Biol Chem 280: 18202-18210.

Bressanelli S, Tomei L, Roussel A, Incitti I, Vitale RL, Mathieu M, De Francesco R, Rey FA. 1999. Crystal structure of the RNAdependent RNA polymerase of hepatitis C virus. Proc Natl Acad Sci 96: 13034-13039.

Bressanelli S, Tomei L, Rey FA, De Francesco R. 2002. Structural analysis of the hepatitis $C$ virus RNA polymerase in complex with ribonucleotides. J Virol 76: 3482-3492.

Caillet-Saguy C, Simister PC, Bressanelli S. 2011. An objective assessment of conformational variability in complexes of hepatitis $\mathrm{C}$ virus polymerase with non-nucleoside inhibitors. J Mol Biol 414: 370-384.

Chinnaswamy S, Yarbrough I, Palaninathan S, Kumar CT, Vijayaraghavan V, Demeler B, Lemon SM, Sacchettini JC, Kao CC. 2008. A locking mechanism regulates RNA synthesis and host protein interaction by the hepatitis C virus polymerase. J Biol Chem 283: 2053520546.

Chinnaswamy S, Cai H, Kao C. 2010a. An update on small molecule inhibitors of the HCV NS5B polymerase: Effects on RNA synthesis in vitro and in cultured cells, and potential resistance in viral quasispecies. J Virus Adapt Treat 2: 73-89.

Chinnaswamy S, Murali A, Li P, Fujisaki K, Kao CC. $2010 \mathrm{~b}$. Regulation of de novo-initiated RNA synthesis in hepatitis C virus RNA-dependent RNA polymerase by intermolecular interactions. J Virol 84: 5923-5935.

Deval J, D’Abramo CM, Zhao Z, McCormick S, Coutsinos D, Hess S, Kvaratskhelia M, Gotte M. 2007. High resolution footprinting of the hepatitis $\mathrm{C}$ virus polymerase NS5B in complex with RNA. J Biol Chem 282: 16907-16916.

Durniak KJ, Bailey S, Steitz TA. 2008. The structure of a transcribing T7 RNA polymerase in transition from initiation to elongation. Science 322: 553-557.

Dutartre H, Boretto J, Guillemot JC, Canard B. 2005. A relaxed discrimination of $2^{\prime}$-O-methyl-GTP relative to GTP between de novo and elongative RNA synthesis by the hepatitis C RNAdependent RNA polymerase NS5B. J Biol Chem 280: 63596368.

Ferrari C, Urbani S, Penna A, Cavalli A, Valli A, Lamonaca V, Bertoni R, Boni C, Barbieri K, Uggeri J, et al. 1999. Immunopathogenesis of hepatitis C virus infection. J Hepatol (Suppl 1) 31: 31-38. 
Harrus D, Ahmed-El-Sayed N, Simister PC, Miller S, Triconnet M, Hagedorn CH, Mahias K, Rey FA, Astier-Gin T, Bressanelli S. 2010. Further insights into the roles of GTP and the $C$ terminus of the hepatitis $\mathrm{C}$ virus polymerase in the initiation of RNA synthesis. J Biol Chem 285: 32906-32918.

Janecki DJ, Beardsley RL, Reilly JP. 2005. Probing protein tertiary structure with amidination. Anal Chem 77: 7274-7281.

Joyce CM, Steitz TA. 1995. Polymerase structures and function: Variations on a theme? J Bacteriol 177: 6321-6329.

Kang SM, Choi JK, Kim SJ, Kim JH, Ahn DG, Oh JW. 2009. Regulation of hepatitis $\mathrm{C}$ virus replication by the core protein through its interaction with viral RNA polymerase. Biochem Biophys Res Commun 386: 55-59.

Kao CC, Yang X, Kline A, Wang QM, Barket D, Heinz BA. 2000 Template requirements for RNA synthesis by a recombinant hepatitis C virus RNA-dependent RNA polymerase. J Virol 74: 1112111128.

Kim MJ, Zhong W, Hong Z, Kao CC. 2000. Template nucleotide moieties required for de novo initiation of RNA synthesis by a recombinant viral RNA-dependent RNA polymerase. J Virol 74: 10312-10322.

Kim YC, Russell WK, Ranjith-Kumar CT, Thomson M, Russell DH, Kao CC. 2005. Functional analysis of RNA binding by the hepatitis C virus RNA-dependent RNA polymerase. J Biol Chem 280: 38011-38019.

Leung AK, Nagai K, Li J. 2011. Structure of the spliceosomal U4 snRNP core domain and its implication for snRNP biogenesis. Nature 473: 536-539.

Liu L, Botos I, Wang Y, Leonard JN, Shiloach J, Segal DM, Davies DR. 2008. Structural basis of toll-like receptor 3 signaling with doublestranded RNA. Science 320: 379-381.

Liu S, Ghalei H, Luhrmann R, Wahl MC. 2011. Structural basis for the dual U4 and U4atac snRNA-binding specificity of spliceosomal protein hPrp31. RNA 17: 1655-1663.

Livak KJ, Schmittgen TD. 2001. Analysis of relative gene expression data using real-time quantitative PCR and the $2^{-\Delta \Delta C}$ Tethod. Methods 25: 402-408.

Lohmann V, Korner F, Koch J, Herian U, Theilmann L, Bartenschlager R. 1999. Replication of subgenomic hepatitis C virus RNAs in a hepatoma cell line. Science 285: 110-113.

Lyakhov DL, He B, Zhang X, Studier FW, Dunn JJ, McAllister WT. 1998. Pausing and termination by bacteriophage T7 RNA polymerase. J Mol Biol 280: 201-213.

Macdonald LE, Zhou Y, McAllister WT. 1993. Termination and slippage by bacteriophage T7 RNA polymerase. J Mol Biol 232: 1030-1047.

Metz B, Kersten GF, Hoogerhout P, Brugghe HF, Timmermans HA, de Jong A, Meiring H, ten Hove J, Hennink WE, Crommelin DJ, et al. 2004. Identification of formaldehyde-induced modifications in proteins: Reactions with model peptides. J Biol Chem 279: 6235-6243.

Novello F, Stirpe F. 1969. Experimental conditions affecting ribonucleic acid polymerase in isolated rat liver nuclei. Effect of nucleoside triphosphate concentration, temperature, ammonium sulphate and heparin. Biochem J 112: 721-727.

O'Farrell D, Trowbridge R, Rowlands D, Jager J. 2003. Substrate complexes of hepatitis C virus RNA polymerase (HC-J4): Structural evidence for nucleotide import and de-novo initiation. $J \mathrm{Mol}$ Biol 326: 1025-1035.

Pettersen EF, Goddard TD, Huang CC, Couch GS, Greenblatt DM, Meng EC, Ferrin TE. 2004. UCSF Chimera-a visualization system for exploratory research and analysis. J Comput Chem 25: 16051612.

Powdrill MH, Bernatchez JA, Gotte M. 2010. Inhibitors of the hepatitis C virus RNA-dependent RNA polymerase NS5B. Viruses 2: 2169-2195.

Ranjith-Kumar CT, Kao CC. 2006. Biochemical activities of the HCV NS5B RNA-dependent RNA polymerase. In Hepatitis $C$ viruses: Genomes and molecular biology (ed. SL Tan), pp. 293-310. Taylor \& Francis, Norfolk, UK.

Ranjith-Kumar CT, Gajewski J, Gutshall L, Maley D, Sarisky RT, Kao CC. 2001. Terminal nucleotidyl transferase activity of recombinant Flaviviridae RNA-dependent RNA polymerases: Implication for viral RNA synthesis. J Virol 75: 8615-8623.

Ranjith-Kumar CT, Gutshall L, Kim MJ, Sarisky RT, Kao CC. 2002a. Requirements for de novo initiation of RNA synthesis by recombinant flaviviral RNA-dependent RNA polymerases. J Virol 76: 12526-12536.

Ranjith-Kumar CT, Kim YC, Gutshall L, Silverman C, Khandekar S, Sarisky RT, Kao CC. 2002b. Mechanism of de novo initiation by the hepatitis C virus RNA-dependent RNA polymerase: Role of divalent metals. J Virol 76: 12513-12525.

Ranjith-Kumar CT, Wen Y, Baxter N, Bhardwaj K, Cheng Kao C. 2011. A cell-based assay for RNA synthesis by the HCV polymerase reveals new insights on mechanism of polymerase inhibitors and modulation by NS5A. PLoS ONE 6: e22575. doi: 10.1371/journal. pone. 0022575 .

Rigat K, Wang Y, Hudyma TW, Ding M, Zheng X, Gentles RG, Beno BR, Gao M, Roberts SB. 2010. Ligand-induced changes in hepatitis C virus NS5B polymerase structure. Antiviral Res 88: 197-206.

Schuwirth BS, Borovinskaya MA, Hau CW, Zhang W, Vila-Sanjurjo A, Holton JM, Cate JH. 2005. Structures of the bacterial ribosome at $3.5 \AA$ resolution. Science 310: $827-834$.

Speers AE, Cravatt BF. 2004. Profiling enzyme activities in vivo using click chemistry methods. Chem Biol 11: 535-546.

Steen H, Jensen ON. 2002. Analysis of protein-nucleic acid interactions by photochemical cross-linking and mass spectrometry. Mass Spectrom Rev 21: 163-182.

Tao Y, Farsetta DL, Nibert ML, Harrison SC. 2002. RNA synthesis in a cage-structural studies of reovirus polymerase $\lambda 3$. Cell 111: 733-745.

Tayon R Jr, Kim MJ, Kao CC. 2001. Completion of RNA synthesis by viral RNA replicases. Nucleic Acids Res 29: 3576-3582.

Temiakov D, Mentesana PE, Ma K, Mustaev A, Borukhov S, McAllister WT. 2000. The specificity loop of T7 RNA polymerase interacts first with the promoter and then with the elongating transcript, suggesting a mechanism for promoter clearance. Proc Natl Acad Sci 97: 14109-14114.

Tomei L, Vitale RL, Incitti I, Serafini S, Altamura S, Vitelli A, De Francesco R. 2000. Biochemical characterization of a hepatitis C virus RNA-dependent RNA polymerase mutant lacking the C-terminal hydrophobic sequence. J Gen Virol 81: 759-767.

Tomei L, Altamura S, Bartholomew L, Biroccio A, Ceccacci A, Pacini L, Narjes F, Gennari N, Bisbocci M, Incitti I, et al. 2003. Mechanism of action and antiviral activity of benzimidazole-based allosteric inhibitors of the hepatitis C virus RNA-dependent RNA polymerase. J Virol 77: 13225-13231.

Toulokhonov I, Artsimovitch I, Landick R. 2001. Allosteric control of RNA polymerase by a site that contacts nascent RNA hairpins. Science 292: 730-733.

Walter G, Zillig W, Palm P, Fuchs E. 1967. Initiation of DNAdependent RNA synthesis and the effect of heparin on RNA polymerase. Eur J Biochem 3: 194-201. 

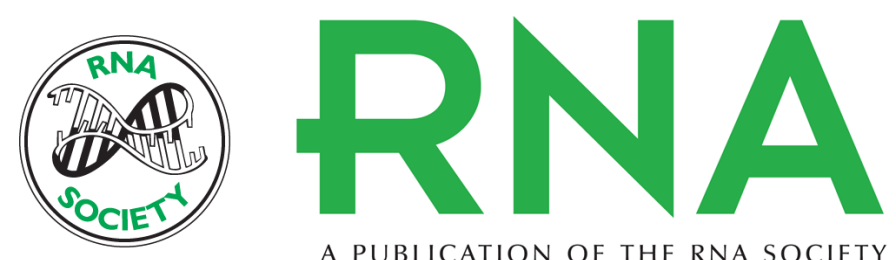

A PUBLICATION OF THE RNA SOCIETY

\section{Identification and functional characterization of the nascent RNA contacting residues of the hepatitis C virus RNA-dependent RNA polymerase}

Robert Vaughan, Baochang Fan, Jin-Sam You, et al.

RNA 2012 18: 1541-1552 originally published online June 26, 2012

Access the most recent version at doi:10.1261/rna.031914.111

Supplemental Material

References

Open Access

License Freely available online through the RNA Open Access option.

Email Alerting Service

Freely available online through the RNA Open Access option. top right corner of the article or click here.
http://rnajournal.cshlp.org/content/suppl/2012/06/12/rna.031914.111.DC1

This article cites 47 articles, 27 of which can be accessed free at: http://rnajournal.cshlp.org/content/18/8/1541.full.html\#ref-list-1

Receive free email alerts when new articles cite this article - sign up in the box at the

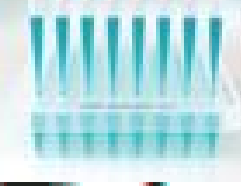

Providing Precise Solutions for your research.

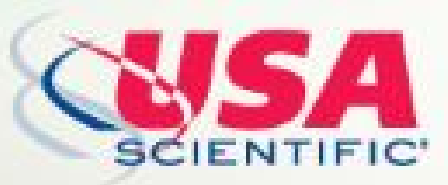

To subscribe to RNA go to:

http://rnajournal.cshlp.org/subscriptions 